Притула А. М., кандидат юридичних наук, доцент, заступник начальника першого відділу управління організації ОРД Департаленту оперативної діяльності Адміністрації Державної прикордонної служби України

\title{
ВИЗНАЧЕННЯ ПОТЕНЦЙНОЇ ПІДСЛІДНОСТІ СЛІДЧИХ ПІДРОЗДІЛІВ ДЕРЖАВНОЇ ПРИКОРДОННОЇ СЛУЖБИ УКРАЇНИ
}

Анотація. У статті розглядається можливість введення слідчих підрозділів до структури Державної прикордонної служби України. Визначається актуальність повноцінної кримінально-процесуальної діяльності Державної прикордонної служби України шляхом надання права здійснення досудового розслідування. Дається поняття підслідності кримінальних проваджень. Встановлюється зв'язок між підслідністю та компетенцією (повноваженнями) відповідного правоохоронного органу. Звертається увага на категорію кримінальних проваджень, що можуть скласти потенційну підслідність Державної прикордонної служби України. Робиться висновок, що підслідністю визнається система правничих рис (властивостей), на підгрунті яких кримінальний процесуальний закон визначає орган досудового розслідування, що має право та зобов'язаний здійснити досудове слідство або дізнання 3 конкретного кримінального провадження й ухвалити по ньому одне 3 підсумкових для стадії досудового розслідування рішення. Визнається потреба внесення змін до чинного матеріального та процесуального кримінального законодавства.

Ключові слова: підслідність, слідчі підрозділи, Державна прикордонна служба України, правоохоронна діяльність, предмет ведення, повноваження, компетенція.

Постановка проблеми. Натепер в Україні нестабільна як соціально-політична внутрішня, так і зовнішня безпекова обстановка. На Сході України проводиться операція Об’єднаних сил, у десяти регіонах було введено воєнний стан, в основному в тих, які межують з Російською Федерацію. У такій небезпечній ситуації на Державну прикордонну службу України (далі - Держприкордонслужба) покладаються специфічні завдання, що пов'язані не тільки з виконанням оперативно-службової діяльності, а й реалізацією бойових задач. Контроль за переміщенням осіб, транспортних засобів через державний кордон здійснюється на таких засадах: протидії тероризму; протидії розвідувально-підривній діяльності іноземних спецслужб; забезпечення права громадян України на виїзд з тимчасово неконтрольованої території, а також із РФ; посилення контролю за переміщенням осіб, транспортних засобів на тимчасово неконтрольовану територію та територію РФ.

Крім того, слід ураховувати, що класична військова агресія, коли застосовуються збройні сили країни, замінена так званою гібридною війною, що характеризується прихованими діями, які спостерігаються переважно в політичній, економічній, інформаційній та спеціальній галузях життедіяльності соціуму. Військовослужбовці агресора для розв'язання окремих завдань диверсійного спрямування залучаються в невеликій кількості. Сутність такого характеру дій полягає в переміщенні центру зусиль із фізичного знищення представників противної сторони в межах масштабної війни до використання «м'якого» інструментарію проти супротивника для дезорієнтації та заміни керівного складу країни, залучення до сфери свого впливу. Все це актуалізує питання не лише правового фундаменту діяльності Держприкордонслужби, а й чіткого визначення її правового статусу через формулювання повноважень в усіх напрямах оперативно-службового, розвідувального, контррозвідувального, оперативно-розшукового, кримінально-процесуального функціонування в повному обсязі (зокрема, завдяки визначенню підслідності та введення інституту слідчих).

Стан наукових досліджень. За роки незалежності України в тому чи іншому ступені інституту підслідності присвятили наукові праці О.В. Баулін, І.Г. Башинська, Л.М. Гусєв, 3.3. Зінатуллін, Н.В. Османова, О.В. Останін, М.С. Салахов, О.В. Селютін, Л.Д. Чулюкін, В.Н. Ягодинський, А.З. Якубова. В рамках національної кримінально-процесуальної доктрини особливе місце посідають дисертаційні роботи Ю.І. Кицана «Підслідність кримінальних справ» та А.А. Омарова «Інститут підслідності в кримінальному провадженні». Особливо цікавими у цьому зв'язку є наукові праці, що присвячені специфіці встановлення підслідності окремих відомств (Н.I. Рязанова, О.В. Бутенко та ін.), а також роботи, в яких розглядається підслідність деяких видів кримінально караних деліктів (Ю.В. Федорчук, О.М. Тараненко, М.I. Карпенко, I.I. Мусієнко, С.О. Гриненко й ін.).

Разом із тим, незважаючи на багатовекторність наукових поглядів на розуміння інституту підслідності, як окремий предмет правовий статус, види діяльності, зокрема потенційна кримінально-процесуальна діяльність майбутніми слідчими Держприкордонслужби, в науковій літературі не досліджувався. Проте умови бойової обстановки на Сході України, як ніколи за період незалежності країни, актуалізують ці проблеми.

Виходячи із зазначеного, метою нашої роботи $є$ створення концептуальної моделі розуміння надання Держприкордонслужбі права здійснення слідчої діяльності в кримінальних провадженнях, що становитимуть її підслідність.

Виклад основного матеріалу. 3 огляду на мету нашого дослідження слід вказати на те, що повноваження будь-якого правоохоронного органу поширюються лише на той обсяг діяльності, що встановлений чинним законодавством. Так, М.С. Городецька та Л.М. Лобойко визначають, що можливим $€$ умовне виокремлення сфери впливу компетентного органу на процесуальні кримінально-правові відносини. Через встановлення кримінально-процесуальної компетенції власних органів держава розподіляє сфери їхнього впливу для забезпечення дієвого функціонування кримінального процесу. Функціональне призначення відповідного правоохоронного органу слід визна- 
ти головним критерієм розподілу сфер впливу між органами, що визначається їх здатністю виконувати завдання кримінального процесу [1, с. 73-74].

М.С. Городецька та Л.М. Лобойко серед структурних елементів предмета відання компетентних органів виокремлюють кримінально-правовий (різновид кримінально караного делікту) та кримінально-процесуальний (характеристики особи, зв’язок кримінальних проваджень, альтернативність можливості провадження в справі, територіальна дія повноважень органу) моменти [1, с. 34]. При цьому кримінально-правовий структурний елемент предмета відання компетентних органів не можна визнати стабільним за обсягом, оскільки він залежить від процесів криміналізації та декриміналізації діянь. Крім того, криміналізація зумовлює розширення предмета відання відповідного правоохоронного органу, а декриміналізація, навпаки, - його звуження [2, с. 176]. Кримінально-процесуальний складник предмета відання також пов'язаний з кримінально караним деліктом і характеристикою окремих елементів його складу. Чинне законодавство визначає предмет відання суб'єктів, що ведуть кримінальний процес, через поняття підслідності, підсудності [3, с. 115].

У теорії кримінального процесу поняття підслідності використовують у двох значеннях: 1) як кримінально-процесуальну категорію, що визначає дотримання загальних умов досудового розслідування; 2) як кримінально-процесуальний інститут [3, с. 115]. Підслідність - це сукупність правил, дотримання яких дає змогу встановити орган, що має здійснювати досудове розслідування кримінального правопорушення [4, с. 4-5].

Протягом останніх років активізувалася робота 3 реформування кримінально-процесуального законодавства та правоохоронної системи в цілому. Функціонування суб' єктів кримінальної юстиції супроводжується дублюванням повноважень, пов'язане 3 відсутністю чіткого визначення та розмежування їхньої компетенції, визнанням пріоритетними завдань, що насправді є другорядними, застосуванням невиправдано ускладнених формальних процедур. Органи кримінальної юстиції мають недосконалі функціональні спроможності, що фактично унеможливлює забезпечення додержання принципу верховенства права в їхній повсякденній діяльності [5].

Стаття 2 Закону України «Про Державну прикордонну службу України» серед основних функцій Держприкордонслужби визначає:

- охорону державного кордону України на суші, морі, річках, озерах та інших водоймах з метою недопущення незаконної зміни проходження його лінії, забезпечення дотримання режиму державного кордону та прикордонного режиму;

- здійснення в установленому порядку прикордонного контролю і пропуску через державний кордон України та до тимчасово окупованої території і з неї осіб, транспортних засобів, вантажів, а також виявлення і припинення випадків незаконного їх переміщення;

- охорону суверенних прав України в прилеглій зоні та іiі виключній (морській) економічній зоні та контроль за реалізацією прав і виконанням зобов'язань у цій зоні інших держав, українських та іноземних юридичних і фізичних осіб, міжнародних організацій;

- ведення розвідувальної, інформаційно-аналітичної та оперативно-розшукової діяльності в інтересах забезпечення захисту державного кордону України згідно із законами Укра- їни «Про розвідувальні органи України» та «Про оперативно-розшукову діяльність»;

- участь у боротьбі з організованою злочинністю та протидія незаконній міграції на державному кордоні України та в межах контрольованих прикордонних районів;

- участь у заходах, спрямованих на боротьбу з тероризмом, а також припинення діяльності незаконних воєнізованих або збройних формувань (груп), організованих груп та злочинних організацій, що порушили порядок перетинання державного кордону України.

Для ефективного виконання покладених на Держприкордонслужбу функцій не просто дискутується питання введення в іiї структуру слідчих підрозділів, а назріла нагальна потреба в його практичному вирішенні. На слідчі органи Держприкордонслужби слід покласти обов'язки проведення досудового розслідування кримінальних правопорушень, передбачених статтями 332 «Незаконне переправлення осіб через державний кордон України», $332^{1}$ «Порушення порядку в'їзду на тимчасово окуповану територію України та виїзду з неї», $332^{2}$ «Незаконне перетинання державного кордону України», а також частиною четвертою статті 358 «Використання завідомо підробленого документа» Кримінального кодексу України (далі - КК України) за умови вчинення їх у разі перетинання або спроби перетинання державного кордону України.

Крім того, Україна Законом від 04.02.2004 № 1433-I ратифікувала Протокол проти незаконного ввозу мігрантів по суші, морю і повітрю, що доповнює Конвенцію ООН проти транснаціональної організованої злочинності (далі - Протокол) [6]. Частина 1 ст. 6 цього Протоколу визначила, що кожна держава-учасниця вживає таких законодавчих та інших заходів, які уможливлять визнання як кримінально караних таких діянь, що вчиняються умисно і з метою отримання, прямо або посередньо, фінансової або іншої матеріальної вигоди, як: а) незаконний ввіз мігрантів; b) створення умов для незаконного ввозу мігрантів: i) виготовлення підробленого документа на в'їзд/ виїзд або посвідчення особи; іi) придбання або надання такого документа або володіння ним; с) надання будь-якій особі, яка не є громадянином відповідної держави або не проживає постійно на іiі території, можливості перебувати в цій державі без дотримання необхідних вимог для законного перебування в ній шляхом використання способів, згаданих у п. (b) ч. 1 ст. 6 цього Протоколу, або будь-яких інших незаконних засобів. Частина 2 ст. 6 цього Протоколу містить положення, згідно з яким кожна держава-учасниця також вживає законодавчих та інших заходів, що уможливлюють визнання як кримінально караних таких діянь: а) замах на скоєння будь-якого злочину, визнаного таким відповідно до ч. 1 ст. 6 цього Протоколу (за умови дотримання основних принципів своєї правової системи); b) участь як спільника у скоєнні будь-якого злочину, визнаного таким відповідно до п.П. а, b (i) або с ч. 1 ст. 6 цього Протоколу, і за умови дотримання основних принципів своєї правової системи - участь як спільника у скоєнні будь-якого злочину, визнаного таким відповідно до п. b (ii) ч. 1 ст. 6 цього Протоколу; с) організацію інших осіб або керівництво ними з метою скоєння будь-якого злочину, визнаного таким відповідно до ч. 1 ст. 6 цього Протоколу [6].

3 огляду на положення розглянутого протоколу до вказаної Конвенції I.I. Митрофановим було запропоновано змінити редакцію статті 332, назвавши іiі «Організація незаконної 
міграції» [7, с. 193-200]. Нами ж пропонується внести цю статтю до КК України під номером $332^{3}$ у такій редакції: «Стаття $332^{3}$. Організація незаконної міграції

1. Організація незаконного в’їзду в Україну, перебування на території України, транзитного проїзду (транзиту) через територію України або виїзду з України іноземця або особи без громадянства або створення для цього умов (організація незаконної міграції), -

карається позбавленням волі на строк від трьох до п'яти років.

2. Те саме діяння, вчинене 3 корисливим мотивом, способом, небезпечним для життя чи здоров'я іноземця або особи без громадянства, або поєднане 3 жорстоким чи таким, що принижує його (iii) гідність, поводженням, шляхом виготовлення, отримання або використання документів для отримання дозволу на імміграцію в Україну, проживання в Україні або громадянства України, або вчинене повторно, або щодо кількох осіб, або групою осіб за попередньою змовою, або службовою особою з використанням своїх службових повноважень, -

карається позбавленням волі на строк від п'яти до семи років 3 конфіскацією майна».

Отже, до переліку кримінальних правопорушень, передбачених статтями $332,332^{1}, 332^{2}, 358$ КК України, досудове розслідування яких має здійснюватися слідчими органами Держприкордонслужби слід додати статтю $332^{3}$ «Організація незаконної міграції» КК України.

Крім того, пропонується віднести до компетенції слідчих органів Держприкордонслужби контрабанду, передбачену статтями 201, 201리 305 КК України, оскільки зазвичай місцем вчинення цих кримінально караних деліктів є державний кордон. Саме тому Держприкордонслужбі простіше якісно, оперативно та повно збирати докази та досліджувати матеріали відповідних кримінальних проваджень. I сам склад контрабанди є доволі ускладненим 3 погляду встановлення всіх обставин у кримінальному провадженні, оскільки йдеться все ж таки про контрабанду культурних цінностей, отруйних, сильнодіючих, вибухових речовин, радіоактивних матеріалів, зброї або боєприпасів (крім гладкоствольної мисливської зброї або бойових припасів до неї), частин вогнепальної нарізної зброї, а також спеціальних технічних засобів негласного отримання інформації, лісоматеріалів або пиломатеріалів цінних та рідкісних порід дерев, лісоматеріалів необроблених, а також інших лісоматеріалів, заборонених до вивозу за межі митної території України, наркотичних засобів, психотропних речовин, їх аналогів чи прекурсорів або фальсифікованих лікарських засобів, тобто специфічних предметів. До цієї групи дотичні кримінально карані делікти, передбачені статтями 149 і 333 КК України.

У зв'язку з цим у разі якщо під час розслідування кримінальних правопорушень, передбачених статтями $332,332^{1}$, $332^{2}, 358$ КК України, будуть встановлені злочини, передбачені статтями 149 «Торгівля людьми», 201 «Контрабанда», $201^{1}$ «Переміщення через митний кордон України поза митним контролем або з приховуванням від митного контролю лісоматеріалів або пиломатеріалів цінних та рідкісних порід дерев, лісоматеріалів необроблених, а також інших лісоматеріалів, заборонених до вивозу за межі митної території України», 305 «Контрабанда наркотичних засобів, психотропних речовин, їх аналогів чи прекурсорів або фальсифікованих лікарських засобів», 333 «Порушення порядку здійснення міжнародних передач товарів, що підлягають державному експортному контролю» КК України, вчинені особою, щодо якої здійснюється досудове розслідування, або іншою особою, якщо вони пов'язані з кримінальними правопорушеннями, вчиненими особою, щодо якої здійснюється досудове розслідування, вони мають розслідуватися слідчими органів Держприкордонслужби.

Висновки. Отже, підслідністю визнається система правничих рис (властивостей), на підгрунті яких кримінальний процесуальний закон визначає орган досудового розслідування, що має право та зобов'язаний здійснити досудове слідство або дізнання 3 конкретного кримінального провадження й ухвалити по ньому одне 3 підсумкових для стадії досудового розслідування рішення:

- скласти в кримінальному провадженні обвинувальний акт;

- скласти клопотання про звільнення особи від кримінальної відповідальності;

- скласти постанову про закриття кримінального провадження;

- скласти клопотання про застосування примусових заходів медичного або виховного характеру.

Виклики часу вимагають введення до складу Держприкордонслужби слідчих підрозділів, для чого необхідно внести відповідні зміни до кримінального процесуального законодавства для визначення їхньої підсудності:

«У Кримінальному процесуальному кодексі України (Відомості Верховної Ради України, 2013 р., №№ 9-13, ст. 88):

1) пункти 8, 17 частини першої статті 3 після слів «органу Державної кримінально-виконавчої служби України» доповнити словами «органу Державної прикордонної служби України»;

2) у статті 38 :

пункт 1 частини першої доповнити підпунктом «д» такого змісту:

«д) органів Державної прикордонної служби України»;

частину третю після слів «органів Державної кримінально-виконавчої служби України» доповнити словами «органів Державної прикордонної служби України»;

3) частину першу статті 143 після слів «органів, що здійснюють контроль за додержанням податкового законодавства» доповнити словами «органів Державної прикордонної служби України»;

4) частину другу статті 214 після слів «органом, що здійснює контроль за додержанням податкового законодавства» доповнити словами «центральним органом виконавчої влади, що реалізує державну політику у сфері охорони державного кордону»;

5) у статті 216 :

у частині другій цифри «332» виключити;

після частини шостої доповнити новою частиною такого 3місту:

«Слідчі органів Державної прикордонної служби України здійснюють досудове розслідування злочинів, передбачених статтями $332,332^{1}, 332^{2}, 332^{3}$, а також частиною четвертою статті 358 Кримінального кодексу України, за умови вчинення їх у разі перетинання або спроби перетинання державного кордону України.

Якщо під час розслідування зазначених злочинів будуть встановлені злочини, передбачені статтями 149, 201, 201', 305, 333 Кримінального кодексу України, вчинені особою, щодо 
якої здійснюється досудове розслідування, або іншою особою, якщо вони пов'язані зі злочинами, вчиненими особою, щодо якої здійснюється досудове розслідування, вони розслідуються слідчими органів Державної прикордонної служби України».

У зв'язку з цим частини сьому - десяту вважати частинами восьмою - одинадцятою;

6) частину шосту статті 232 після слів «органу Державної кримінально-виконавчої служби України, на території юрисдикції якого перебуває така особа» доповнити словами «органу Державної прикордонної служби України»;

7) у частині п'ятій статті 246 :

абзац четвертий після слів «Державної кримінально-виконавчої служби України» доповнити словами «територіального органу центрального органу виконавчої влади, що реалізує державну політику у сфері охорони державного кордону»;

абзац п'ятий після слів «керівником Державної кримінально-виконавчої служби України» доповнити словами «Головою Державної прикордонної служби України»;

8) у частині четвертій статті 263 після слів «Національної поліції» доповнити словами «Державної прикордонної служби України».

\section{Jimepamypa:}

1. Городецька М.С., Лобойко Л.М. Кримінально-процесуальна компетенція слідчого органів внутрішніх справ: монографія. Дніпропетровськ: Дніпропетров. держ. ун-т внутр. справ: Ліра-ЛТД, 2010. $232 \mathrm{c}$

2. Сабадаш В.П., Єна І.В. Предмет відання прокурора в досудовому провадженні. Вісник Запорізького національного університету. 2009. № 2. С. 174-180.

3. Лисецький О.О. Слідчий як суб'єкт кримінального провадження: дис. ... канд. юрид. наук. Харків, 2018. 244 с.

4. Омаров А.А. Інститут підслідності в кримінальному провадженні: автореф. дис. ... канд. юрид. наук. Харків, 2017. 20 с.

5. Про рішення Ради національної безпеки і оборони України від 15 лютого 2008 р. «Про хід реформування системи кримінальної юстиції та правоохоронних органів»: Указ Президента України від 8 квітня 2008 р. №311/2008. URL: http://zakon0.rada.gov.ua/laws/ show/311/2008 (дата звернення: 05.12.2018).

6. Протокол проти незаконного ввозу мігрантів по суші, морю i повітрю, що доповнює Конвенцію Організації Об'єднаних Націй проти транснаціональної організованої злочинності: Резолюція 55/25 Генеральної Асамблеї ООН від 15 листопаду 2000 року. Офіційний вісник України. 2006. № 14. Ст. 1058.

7. Митрофанов I.I. Сприяння організації переправлення осіб через державний кордон: що криється за цим поняттям? Публічне право. 2015. № 3. С. 193-200.
Притула А. М. Определение потенциальной подследственности следственных подразделений Государственной пограничной службы Украины

Аннотация. В статье рассматривается возможность введения следственных подразделений в структуру Государственной пограничной службы Украины. Определяется актуальность полноценной уголовно- процессуальной деятельности Государственной пограничной службы Украины путем предоставления права осуществления досудебного расследования. Обращается внимание на категорию уголовных производств, которые могут составить потенциальную подследственность Государственной пограничной службы Украины. Делается вывод, что подследственностью признается система юридических свойств, на основе которых уголовный процессуальный закон определяет орган досудебного расследования, что имеет право и обязан осуществить досудебное следствие или дознание конкретного уголовного производства и принять по нему одно из итоговых для стадии досудебного расследования решений.

Ключевые слова: подследственность, следственные подразделения, Государственная пограничная служба Украины, правоохранительная деятельность, предмет ведения, полномочия, компетенция.

Prytula A. On potential jurisdiction of investigative units of the State Border Guard Service of Ukraine

Summary. The article considers the possibility of introducing investigative units into the structure of the State Border Guard Service of Ukraine. The relevance of the full criminal-procedural activity of the State Border Guard Service of Ukraine is determined by granting the right to conduct a pre-trial investigation. The concept of criminal proceedings is defined. The link between the jurisdiction and the competence (authority) of the appropriate law-enforcement body is also highlighted. The article also draws attention to the category of criminal proceedings that may constitute a potential jurisdiction of the State Border Guard Service of Ukraine. It is concluded that the jurisdiction is a system of legal aspects (characteristics), on the basis of which the criminal procedural law determines a pre-trial investigation body, which has the right and obligation to conduct a pre-trial investigation or inquiry during a specific criminal proceeding and to approve one of the final decisions for the stage of pre-trial investigation. The need to amend the current material and procedural criminal legislation is recognized in the article.

Key words: investigation, investigative units, State Border Guard Service of Ukraine, law enforcement activity, subject of jurisdiction, authority, competence. 